\title{
Annual Performance Planning Information System with Enterprise Architecture Modelling the Secretariat of the Central Java Province Parliament Used Framework Togaf
}

\author{
Ginanjar Wiro Sasmito
}

\begin{abstract}
Use of information systems technology with the annual performance plan is not currently aligned with the needs of the secretariat of the Central Java Provincial Parliament the truth, thus allowing the application of information systems overlap. The need for the secretariat of the Central Java Provincial Parliament can only be answered by considering the factors in pengembangnnya integration, the real goal of integration is to reduce disparities in the system development process. To decrease the gap, it would require a paradigm shift in planning, designing, and managing information systems called enterprise architecture. One model is the enterprise architecture framework TOGAF. TOGAF Enterprise Architecture modeling framework to produce a blue print on an information system that integrates the annual performance plan, accelerate the process of reporting annual performance plan to the leadership of Secretary (Central Java Provincial Parliament) so that more effective and efficient.
\end{abstract}

Index Terms-Enterprise architecture, framework togaf, annual performance planning information system

\section{INTRODUCTION}

With the increasing needs in the functioning of the organization led to the use of information systems in organizations is needed, as well as the organization of government, namely the Parliament Secretariat of Central Java Province. Use of information systems technology with the annual performance plan is not currently aligned with the needs of the Secretariat of the Central Java Provincial Parliament the truth, thus allowing the application of information systems overlap. These conditions make the annual performance plan information system cannot be utilized as expected based on the mission and purpose of application of the system, the efficiency and effectiveness in fulfilling the organization's needs, ranging from meeting the needs of the highest levels in the organization to the needs of the most under operational needs.

Performance planning is a process of further elaboration of objectives and programs set out in the strategic plan (strategic plan) that includes a period of years. Annual performance plan describes the annual event which will be implemented by government agencies and key performance indicators along with its targets under the program, policies, and objectives set out in the strategic plan [1].

The need for the Secretariat of the Central Java Provincial Parliament can only be answered by considering the factors

Manuscript received January 20, 2013; revised March 20, 2013.

Ginanjar Wiro Sasmito is with D3 Computer Engineering, Harapan Bersama Polytechnic, Jln. Mataram No. 09 Tegal (e-mail: anjar.dosen@gmail.com). in pengembangnnya integration; the real goal of integration is to reduce disparities in the system development process. To decrease the gap, it would require a paradigm shift in planning, designing, and managing information systems called enterprise architecture.

Enterprise architecture is a knowledge base consisting of the elements of internal and external business environment and the relationship between the two [2]. With the increasing requirements for smoothness and alignment of business systems, enterprise architecture has become an important field [3] and has attracted the attention of many researchers, IT experts and a variety of other business actors [4], [5].

There are various models of enterprise architecture, but in this study used a model enterprise architecture framework TOGAF, TOGAF are due within the framework of detailed methods and tools for the implementation process [6]. $\mathrm{R}$ Harrison [7] meyatakan that TOGAF (The Open Group Architecture Technique) is a detailed framework and support tools for developing an enterprise architecture used freely by any organization that developed for the design, evaluation, and building IT blueprint. With the use of enterprise architecture framework TOGAF, it can produce a model and framework (blue print) in developing an information system that integrates the annual performance plan that would meet the needs of the Parliament Secretariat of Central Java Province.

\section{REVIEW OF LITERATURES}

Ade Supriatna [8] analyzes the application of TOGAF and COBIT information technology governance as a proposal to the Ministry of Energy and mineral resources. The results of these studies are in the form of products (architecture framework process) and standards - standards of governance of information technology to support organizational activities in preparation for the beginning of the ministry of energy and mineral resources in the planning-based electronic tenders for the construction / management of mineral and gas resources in Indonesia as well and transparent. So the management of resources natural resources is done with regard to the impact on the environment responsibly.

Iyan Supriyana [9] applies the model of business architecture, information systems and technology in the Coordinating Agency for Surveys and Mapping (BAKOSURTANAL) based on TOGAF. Based on these studies, produced the BAKOSURTANAL in building blue print must implement a service-based architecture that follows the framework of SOA, ERP, and executive 
dashboard that is used for decision making officials structural, and Data Warehouse for data integration in the development of E-Gov both spatial and non spatial data.

Abdul Aziz [10] in a research produces a SIMPEG (Human Resources Information System) based online. The draft SIMPEG online has produced a blueprint (blue print) web-based. SIMPEG online blueprint has been implemented with prototype development methods. SIMPEG can store data generated employment administration proposal process (promotion, provisional release, active working again, and learning tasks) and their completeness of the file process. In general evaluation of the analysis and design of system architecture with TOGAF method is reliable and in accordance with user needs.

Taleb Mohamed and Omar Cherkaoui [11] conducted a study pattern-oriented approach to enterprise architecture: TOGAF framework, the study also noted that when using TOGAF framework and did not notice the pattern-oriented approach to business analysis cannot be used as a solution can minimize or suppress poor performance and scalability. The study has also identified and proposed ten categories of patterns and examples for the pattern-oriented architecture framework TOGAF are used as a strategy in the design process.

\section{RESEARCH METHODE}

\section{A. Organization Analyzes}

Under Government regulations, 03 in 2001, the Parliament Secretariat Organizational Structure of Central Java province following: (Fig. 1-Fig. 7)

Each section on the Parliament Secretariat responsible is to the Secretary of the Council. In performing their duties, both the Secretary of Parliament, Head of Department, Head of Sub Division and Chairman of the Functional Group shall apply the principle of co-ordination and integration of vertical and horizontal sync, well into their environment each and between organizational units in accordance with their duties respectively-each.

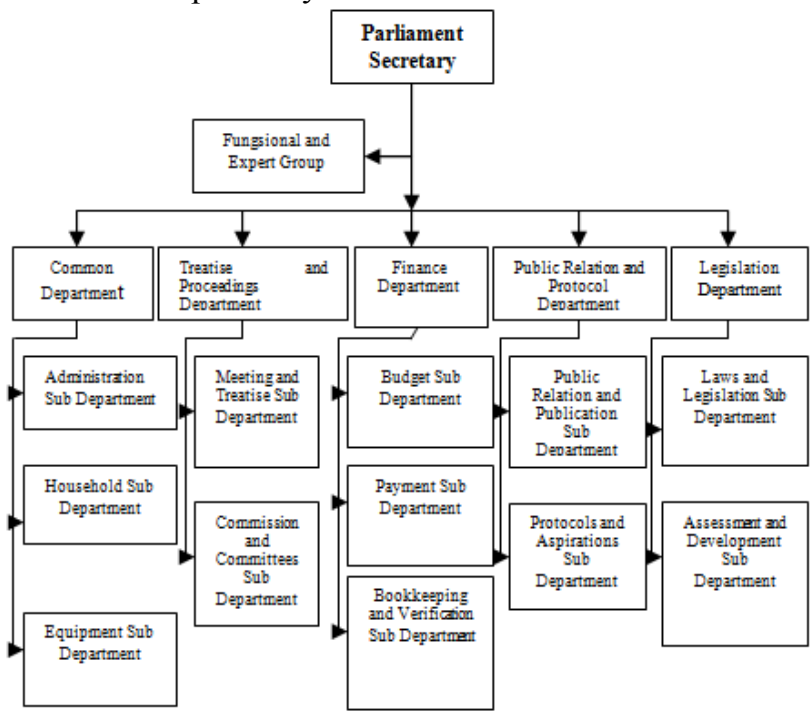

Fig. 1. Parliament secretariat organizational structure of central java province

\section{B. Problems Framework}

Support an Annual Performance Plan for Information
Systems at the Secretariat of the Central Java Provincial Parliament quality is a necessity due to the effectiveness, validity and reliability of the information generated based on the data that has been entered. Such circumstances require that the Central Java Provincial Parliament Secretariat to make a better architectural models. In 2008 the development of the Annual Performance Plan for Information Systems at the Parliament Secretariat of Central Java is done by intranet technology. But there are still many obstacles in its implementation because not all sections and sub-sections in the intranet, so that the process of data integration cannot be run properly and optimally. In fact, as leader, Secretary of parliament cannot know and get reporting Annual Performance Plans quickly due to the Secretary of Parliament have not been integrated on the network can access the intranet for Information Systems Annual Performance Plan.

\section{Annual Performance Plan Information System Problems}

Annual Performance Plan Information Systems Development efforts need to be followed up with database maintenance, enhancement software, performance evaluation and utilization of information system to support the formulation of the Annual Performance Plan program planning work at the Parliament Secretariat of Central Java Province. Database maintenance can be done by updating and validation data. Increasing Annual Performance Plan Information System software must be adapted to existing systems, user needs, and the development of increasingly rapid technological changes and an evaluation of the performance of Annual Performance Plan Information Systems.

\section{Research Framework}

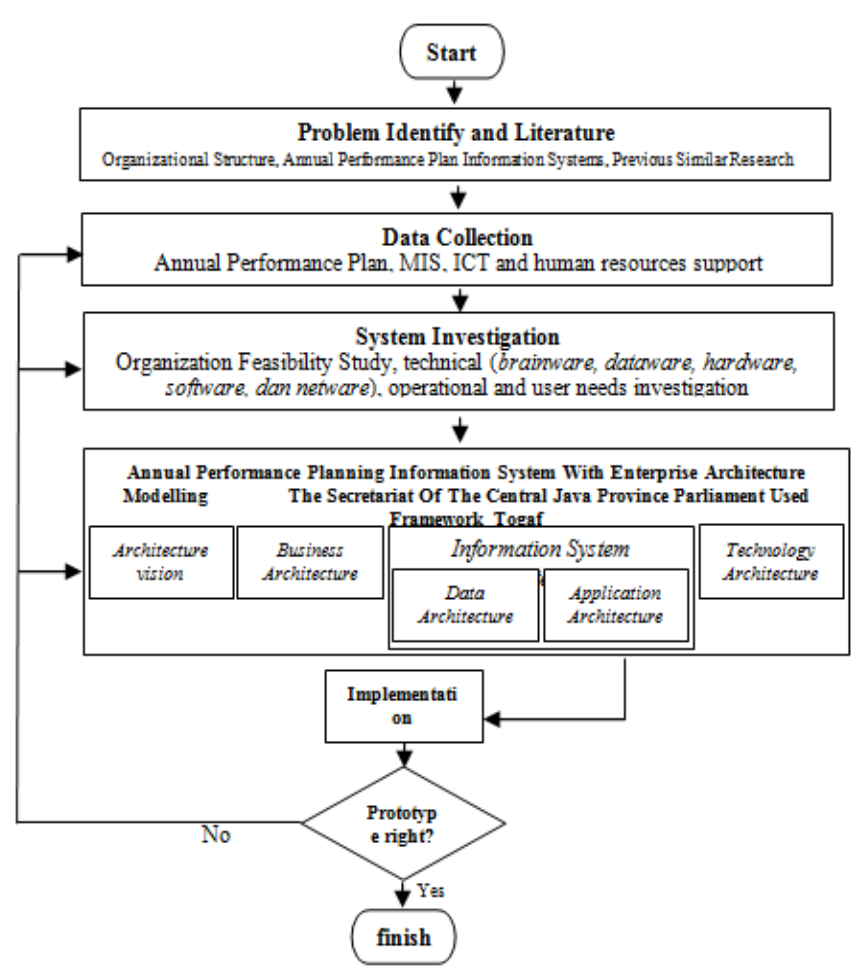

Fig. 2. Research design.

In developing an information system, the entire process 
must be passed through several stages. Stages include planning systems according to user requirements, system analysis, system design, system implementation, and system maintenance. The output of the resulting system planning requirements according to user needs. Analysis and design of the system generate logical design specification and implementation of the system produced teknis.dari software that can be used, as well as maintenance of the system generated application tested and ready to be operationalized [12]. Based on the research phase, the research steps can be seen in the following framework.

\section{RESULT AND EXPLANATION}

\section{A. Technology Architecture Analisys}

In analyzing the technology architecture is necessary to identify the principles underlying technology platform selecting a platform. This research will be identified using the technology platform principle 7 (seven) in order to identify focus areas. The seven areas are as follows:

\begin{tabular}{|c|c|c|c|c|c|c|}
\hline \multicolumn{7}{|c|}{ Technology architectur } \\
\hline 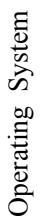 & 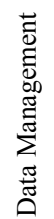 & 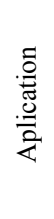 & 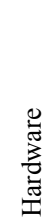 & 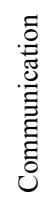 & 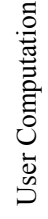 & 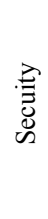 \\
\hline
\end{tabular}

Fig. 3. Principal and platform of SI/TI [13]

\section{1) Operating system}

Based on the need for information systems that have been analyzed, then the research proposed in the development of Information Systems Annual Performance Plan Secretariat of the Central Java Provincial Parliament using LINUX operating systems because Linux is an open source operating system that can be easily obtained than the operating system has a license, LINUX as well has a superior safety system designed for multiuse.

\section{2) Data management}

The design of the proposed data management refers to the system of decentralized data, ie, every part of the Secretariat of the Central Java Provincial Parliament dapats menginputkan Annual Performance Plan, but each piece can only see their own reporting and has diinputkannya reporting system remains centralized to the Secretary of the Central Java Provincial Parliament. This is done so that the effectiveness and efficiency of an information system can be achieved easily.

\section{3) Aplication}

Application Information System Annual Performance Plan for the Central Java Provincial Parliament created with Borland Delphi. Delphi is the IDE compiler for Pascal programming language and software development environment. The appearance Application Performance Plan Annual Information Systems Council of Central Java province is as follows:

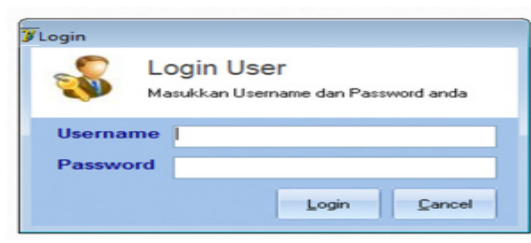

Fig. 4. Application log in.

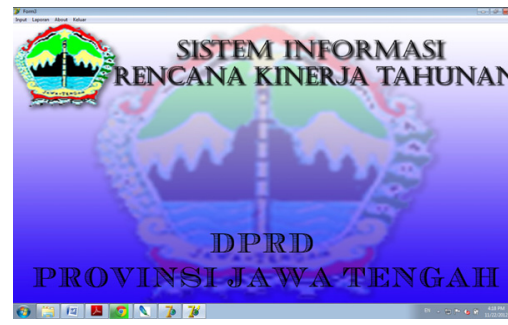

Fig. 5. Starting graphical

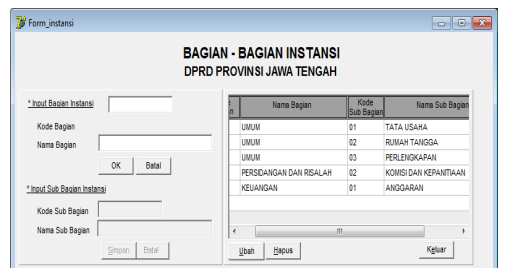

Fig. 6. Instantion part input

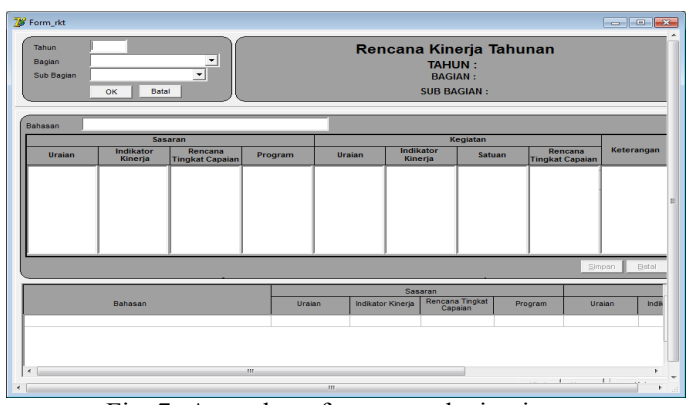

Fig. 7. Annual performance planing input.

\section{4) Hardware}

In this study, an Annual Performance Plan information system is planned so that every part of the Secretariat of the Central Java Provincial Parliament could menginputkan individual performance plan to be reported directly to the secretary of the Central Java Provincial Parliament. In this case, the hardware support for system information required is as follows:

- Computers are used as a server at the General Secretariat of the Council of Central Java Province

- Computers are used as a database server at the General Secretariat of the Council of Central Java Province.

- Computers are used as an administrator at the General Secretariat of the Council of Central Java Province.

- Computers are used as a client to the Secretary of the Central Java Provincial Parliament.

- Computers are used in every section administrator at the Secretariat of the Central Java Provincial Parliament.

- Enhanced Category 5 UTP cable to connect to the switch and the server administrator to the database server

- Connector : RJ 45

- Switches that support connector RJ 45, NIC (Network Interface Card) and UPS. 


\section{5) Communication}

The design of the proposed communication is to use the intranet. Khoe Yao Tung [14] says: Intranet is a LAN that uses standard Internet communication and all facilities, is like surfing in a local environment. Intranet is a private network (private network) that uses Internet protocols (TCP / IP). Elections due intranet effectiveness and efficiency of information delivery and data security over the data more secure. Besides intranet can reduce the cost of information needs collaboration, workflow, and enterprise connectivity.

\section{6) User computation}

As government agencies are required to produce a good performance, Parliament Secretariat of Central Java province to keep abreast of current technology is increasing rapidly. Availability of computers that are connected to the intranet network by 27 units and are not connected to the intranet as much as 33 units. Among the average computer already has a specification Dual Core and Core 2 Duo although there are still some that use the Pentium 4. Therefore, the computer is something that is considered a necessity in working with the Secretariat of the Central Java Provincial Parliament.

\section{7) Security}

The use of a firewall is a must on network security in Central Java Provincial Parliament Secretariat. A firewall is a software (software) or hardware (Hardware) that filters all traffic data (traffic) between the computers, the computer network at home or in the office with the Internet [15].

Because of this research proposal using the LINUX operating system, then the proposed firewall is to use iptables. IPTasbles is a tool in the LINUX operating system that serves as a tool to filter the data traffic [16]. Some advantages IPTables are: able to inspect packets and working with ICMP and UDP as well as TCP connections, simplifying the behavior of the packets in the attempt to negotiate a built-in chain, is able to filter out the flags, TCP options-address and MAC address.

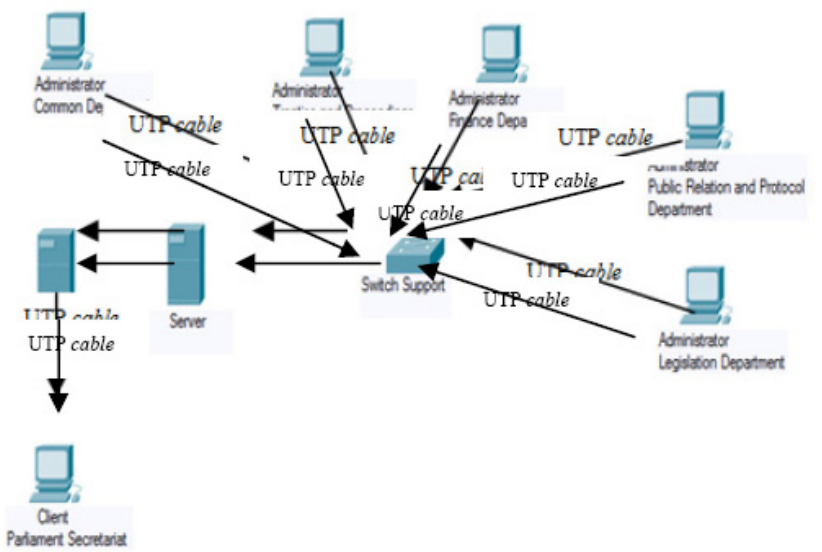

Fig. 8. Architectural design of the technology plan information system annual performance council, central java province.

Besides, to protect all the infrastructure / IT from viruses, spam, and malware, it is advisable to use a combination of the installation of anti-virus, anti-spam, and anti-malware either on its own server, and on each client. It is advisable to use an anti-virus that is client / server or server manageable, so workstations only need to innovate through the server, no need to go through the internet, besides anti-virus client / server easier for network administrators to install and manage remotely.

\section{B. Implementation}

Based on the seven areas, it can be made conceptual technology configurations. The configuration of these technologies will provide guidance on how to utilize an Information Systems Plan Annual Performance in Central Java Provincial Parliament Secretariat to the fullest. The chart of the model configuration is as follows.

\section{RESUME}

Based on the research that has been done, it can take some conclusions as follows:

- TOGAF Enterprise Architecture modeling framework will be able to produce a blue print on an information system that integrates the annual performance plan

- TOGAF Enterprise Architecture Modeling framework will accelerate the process of reporting annual performance plan to the leadership of Secretary (Central Java Provincial Parliament) so that more effective and efficient.

By utilizing models TOGAF Enterprise Architecture framework, the Annual Performance Plan for Information Systems Council of Central Java province will meet the criteria reasoned, cohesive, adaptable, technology independent, domain neutral, and scalable. However, only one criterion not met the criteria of vendor independent, meaning Information System Annual Performance Plan and the subsequent development of the system depends on the developer (vendor).

\section{REFERENCE}

[1] BPKP, Akuntabilitas Instansi Pemerintah (edisi kelima), Diklat Pembentukan Auditor Ahli, Pusat Pendidikan dan Pelatihan Pengawasan BPKP, 2007.

[2] A. Sasa and M. Krisper, Analytical models for the business and information architecture, applied informatics Xviii, 2010.

[3] M. Wilkinson, "Designing an 'adaptive' enterprise architecture," BT Technology Journal 24, pp. 81-92, 2006.

[4] H. Jonkers, M. Lankhorst, H. ter Doest, F. Arbab, H. Bosma, and R Wieringa, "Enterprise architecture: management tool and blueprint for the organization," Information Systems Frontiers, pp. 63-66, 2006.

[5] P. Johnson, R. Lagerstrom, P. Narman, and M. Simonsson, "Enterprise architecture analysis with extended influence diagrams,", Information Systems Frontiers , pp. 163-180, 2007.

[6] S. Lusa and S. D. Indra, Kajian Perkembangan dan Usulan Perancangan Enterprise Architecture Framework, Snati: Yogyakarta, ISSN. 1907-5022, 2011

[7] R. Harrison, TOGAF Version 8.1.1 Enterprise Edition Study Guide, New York: Van Haren Publishing, 2007.

[8] S. Ade. Analisa Penerapan TOGAF dan COBIT dalam Tata Kelola Teknologi Informasi sebagai Usulan pada Kementrian Energi dan Sumber Daya Mineral, semnasIF, ISSN. 1979-2328. Yogyakarta, 2010.

[9] S. Iyan, Model Arsitektur Bisnis, Sistem Informasi dan Teknologi di Bakosurtanal Berbasis TOGAF, Telkomnika, Bogor, Bakosurtanal, ISSN. 1693-6930, vol. 8, no. 1, 2010.

[10] A. Abdul, Rancang Bangun Sistem Informasi Manajemen Kepegawaian dengan Metode The Open Group Architechture Framework (TOGAF), Bogor, Sekolah Pascasarjana IPB, 2011.

[11] T. Mohamed and C. Omar, "Pattern-Oriented Approach for Enterprise Architecture: TOGAF Framework," Journal of Software Engineering and Applications, Scientific Research, vol. 5, pp. 45-50, 2012

[12] P. Harun "Perancangan Sistem Informasi Jabatan Fungsional Badan Litbang Pertanian," Journal Informatika Pertanian, vol. 12, pp. 31-44, 2003. 
[13] E. B. Setiawan, Perancangan Strategis Sistem Informasi IT Telkom untuk menuju World Class University, Di dalam: Seminar Nasional Aplikasi Teknologi Informasi, Yogyakarta, Hlm. 97-101, 20 Juni 2009.

[14] T. K. Yao, Teknologi Jaringan Intranet, Yogyakarta: Andi Yogyakarta, 1997.

[15] B. Komar, R. Beekelaar, and J. Wettern, Firewalls For Dummies $2^{\text {nd }}$ Edition, Willey Publishing Inc., New York, 2003.

[16] R. Michael, Linux Firewalls, William Pollock Publishing, 2007.

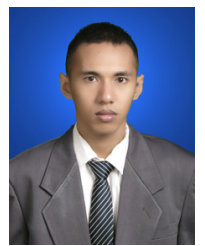

Ginanjar Wiro Sasmito was born in Brebes cityIndonesia on 13 February 1986. Get Master of Computer from Diponegoro University. Every day work as lecturer in study program computer engineering and as head of research and community service at the Harapan Bersama Polytechnic. Authors incorporated in the organization APTIKOM (Association of informatics and computer college), PII (Indonesian Engineers Unity). Authors also believed to be a leader the council DIKDASMEN (primary and secondary education) Muhammadiyah in Brebes city. 